\title{
Impact of INM Practices on Vegetative Growth and Flowering of Hybrid Gerbera (Gerbera jamesonii B.) cv. Shimmer in Open Condition
}

\author{
Bishnupada Giri* and Sashikala Beura \\ Department of Floriculture and Landscaping, College of Agriculture, \\ OUAT, Bhubaneswar, India \\ *Corresponding author
}

\begin{tabular}{|l|}
\hline Key w or d s \\
RDF, Azospirillum, \\
$\begin{array}{l}\text { Vermicompost, } \\
\text { PSB, Azotobacter }\end{array}$ \\
\hline Article Info \\
\hline $\begin{array}{l}\text { Accepted: } \\
18 \text { May } 2020 \\
\text { Available Online: } \\
10 \text { June } 2020\end{array}$ \\
\hline \hline
\end{tabular}

\section{A B S T R A C T}

The present investigation on Impact of INM practices on growth and flowering of Gerbera was carried out in premises of Biotechnology cum Tissue Culture Centre OUAT Bhubaneswar during 2015-16 and 2016-17. The objective of the study was to develop an INM model for cut flower production of gerbera in open field condition. Eight fertilization treatment combinations were used consisting of $100 \% \mathrm{RDF}$, Vermicompost, $75 \%$ RDF, PSB, Azospirillum, Azotobacter, and foliar application of macro and micro elements. The result revealed that application of $75 \% \mathrm{RDF}$ $\left(15: 10: 30 \mathrm{~g} \mathrm{NPK} / \mathrm{m}^{2}\right)+$ Vermicompost+ $\left(25 \mathrm{~g} / \mathrm{m}^{2}\right)+$ Azospirillum/ Azotobacter $\left(20 \mathrm{~g} / \mathrm{m}^{2}\right)+\mathrm{PSB}+$ macro and micro element spray increased all of vegetative parameters of gerbera. In flowering parameter, number of flower/plant were maximum in the same treatment. It can be concluded that reducing level of chemical fertiliser to $75 \%$ RDF along with application of different organic source of nutrient can improve flower yield of gerbera in open field condition.

\section{Introduction}

Gerbera (Gerbera jamesonii B.) also known as Transvaal daisy, Barbeton daisy or African daisy belonging to family Asteraceae occupies $5^{\text {th }}$ place as cut flower in international flower trade (Sujatha et al., 2002). It is popular because of it is attractive colour, long vase life and suitability for long distant transport (Bose et al., 2003 and
Chauhan, 2005). It is used for fresh and dry flower arrangement, exhibition, decoration, bouquet preparation (Patra et al., 2015). Local and improved cultivar is grown in garden, flower bed, pots, borders, dish garden and rock garden. Flowers are of different colour like white cream, yellow, pink, orange, brick red, scarlet, salmon, maroon and bicolor and are available in single, semi-double or double form. 
Use of chemical fertiliser gradually deteriorates soil health and fertility. Leaching of fertiliser to water also creates environmental hazards. In such situation adoption of INM practices is better option to address such problem. Integrated nutrient management reduce fertiliser use and increases productivity and quality of gerbera (Majumdar et al., 2014).

\section{Materials and Methods}

The present study was conducted in premises of Bio-technology cum Tissue Culture Centre, Odisha University of Agriculture Technology, Bhubaneswar from Nov. to Oct. 2015-16 and 2016-17 in open condition.

The experimental site is situated $63 \mathrm{~km}$ away from Bay of Bengal at an altitude of $25 \mathrm{~m}$ above MSL and extended between $20^{\circ} 15^{\prime}$ North latitude and $85^{\circ} 50^{\prime}$ East longitude. The average rainfall of the site is $1646 \mathrm{~mm}$. The maximum temperature during the experimental period was $38.8{ }^{0} \mathrm{C}$ to $40.8^{0} \mathrm{C}$ and minimum temperature was $14.1^{\circ} \mathrm{C}$ to $15.2^{\circ} \mathrm{C}$. The relative humidity during the experimental period was $37 \%$ to $94 \%$. The experimental soil was sandy loam with $\mathrm{pH}$ 5.83, EC $0.64 \mathrm{ds} / \mathrm{m}$, OC $0.475 \%$; N 125 $\mathrm{kg} / \mathrm{ha}, \mathrm{P}_{2} \mathrm{O}_{5} 67.1 \mathrm{~kg} / \mathrm{ha}, \mathrm{K}_{2} \mathrm{O} 166.6 \mathrm{~kg} / \mathrm{ha}$. The growing media was composed of Soil, FYM and Coco peat in 1: 1: 1 proportion.

Earthen pot with a hole at the bottom was used for planting. The pot was filled with soil mixture. Four leaved tissue culture plantlets of gerbera cv. Shimmer a variety suitable for protected cultivation were used for planting. Experiment was laid down in Completely Randomized Design (CRD) with eight treatment combination and three replications per treatment. There were 30 plants per treatment making a total population of 240 plants. The treatment consisted of RDF $(15: 10: 30 \mathrm{~g}$ NPK/10 plants) in alternate month $\left(\mathrm{T}_{1}\right), \mathrm{RDF} @ 15: 10: 30 \mathrm{~g}$ NPK/10 plants in every month $\left(\mathrm{T}_{2}\right), 75 \% \mathrm{RDF}+$ Vermicompost @25 g/10 plants $\left(\mathrm{T}_{3}\right), 75 \%$ RDF + Vemicompost @ 25 g/10 plants + Azospirillum @20 g/10 plants + PSB @ 20 $\mathrm{g} / 10$ plants $\left(\mathrm{T}_{4}\right), 75 \% \mathrm{RDF}+$ Vermicompost @ $25 \mathrm{~g} / 10$ plants+ Azotobacter @ $20 \mathrm{~g} / 10$ plants + PSB@20 g/10 plants $\left(\mathrm{T}_{5}\right), 75 \%$ RDF + vermicompost @25 g/10 plants + sprayable macro and micro elements @ $2 \mathrm{ml} / \mathrm{l}$ $\left(\mathrm{T}_{6}\right), 75 \% \mathrm{RDF}+$ vermicompost @ $25 \mathrm{~g} / 10$ plants + Azospirillum @ 20 g/10 plants + PSB @ $20 \mathrm{~g} / 10$ plants + sprayable macro and microelements @ $2 \mathrm{ml} / \mathrm{l})\left(\mathrm{T}_{7}\right)$ and $75 \% \mathrm{RDF}$ + vermicompost @ $25 \mathrm{~g} / 10$ plants + Azotobacter@20 g/10 plants + PSB @ 20 $\mathrm{g} / 10$ plants + sprayable macro and micro elements@2 ml/l $\left(\mathrm{T}_{8}\right)$.

The bioferitliser were applied after incubation with vermicompost for 7 days. Recommended dose of fertilizer were applied 3 month after planting as top dressing and subsequently as per treatment.

The observation were recorded from 5 randomly selected plant within each replication of treatment for different vegetative parameters like plant spread, number of leaves/plant, leaf length, length of petiole, leaf width, number of suckers/plant, leaf area and chlorophyll content.

The data collected on vegetative and flowering parameters were analysed statistically following the method of Gomez and Gomez (1984) using one way ANOVA in CRD. A comparison of treatment means were done at $5 \%$ level of significance $(\mathrm{P}=0.05)$.

\section{Results and Discussion}

The results of the experiment obtained in the year 2015-16 and 2016-17 were pooled and presented in Table 1 and Table 2 and discussed under the following headings. 


\section{Plant spread}

Pooled data of both the consecutive year (Table-1) revealed that in winter plants applied with $75 \% \mathrm{RDF}+$ Vermicompost + $\mathrm{PSB}+$ Azospirillum + sprayable macro and micro elements $\left(\mathrm{T}_{7}\right)$ represent maximum plant spread $(77.19 \mathrm{~cm})$ which was at par with $\mathrm{T}_{8}$ (75 \% RDF+ Vermicompost + PSB+ Azotobacter + sprayable macro and micro elements), $\mathrm{T}_{4}(75 \% \mathrm{RDF}+$ Vermicompost+ $\mathrm{PSB}+$ Azospirillum) and $\mathrm{T}_{5}(75 \% \mathrm{RDF}+$ Vermicompost+ PSB+ Azotobacter) whereas minimum plant spread $(55.84 \mathrm{~cm})$ was observed in $\mathrm{T}_{2}$ (RDF in every month). Increase in plant spread in $\mathrm{T}_{8}, \mathrm{~T}_{7}, \mathrm{~T}_{5}, \mathrm{~T}_{4}$ might be due to beneficial effect of vermicompost when applied with biofertiliser incubated in it. Vermicompost contain several growth hormones enzymes and rich in plant nutrients which accounts for profuse vegetative growth of gerbera.

Besides, bio-fertiliser like PSB, Azospirillum, Azotobacter stimulate growth of plant by mobilizing or solubilising plant nutrient in soil solution which are readily taken by plants. On the other hand lowest plant spread in $\mathrm{T}_{2}$ (RDF in every month) might be due to application of $100 \%$ RDF in every month which create residual toxicity of fertiliser in soil resulting poor and sick growth of plant. When level of fertiliser was increased (as in $\mathrm{T}_{2}$ ) which was more than the requirement of plant, it resulted decrease in plant spread.

Similar findings have been obtained by Kathiresan and Venketas (2002) with respect to application of vermicompost+ Azospirillum $+75 \% \mathrm{RDF}$ in gladilous, Mathew and Shingh (2003) with respect to application of Azospirillum+ PSB+ Azotobacter in marigold. Similar trends in plant spread were also observed in summer and rainy season.

\section{Number of leaves/plant}

The data from Table-1 indicated that there was significant variation among treatments with respect to number of leaves/plant. In winter season the maximum number of leaves (25.23 no.) were found in $\mathrm{T}_{7}(75 \% \mathrm{RDF}+$ vermicompost $+\mathrm{PSB}+$ Azospirillum + sprayable macro and microelements) which was at par with $\mathrm{T}_{8} \quad(75 \%$ RDF + Vermicompost + PSB + Azotobacter + sprayable macro and micro element). Similar findings have been obtained by Seetha and Gowda (2002), Kathiresan and Venketasha (2002) with respect to application of Vermicompost and $75 \% \mathrm{NPK}$ as RDF in Gerbera.

The minimum number of leaves (13.81) were found in $\mathrm{T}_{2}$ (RDF in every month) in winter season which shows that balanced fertilisation was required for production maximum number of leaves which corroborates with the finding of Khosa et al., (2011) with respect to application of NPK + micro nutrient in Gerbera. A similar trend in number of leaves/plant was also observed in summer and rainy season.

\section{Length of leaf and leaf width}

It was evident from the Table-1 that in winter season maximum length of leaf $(39.98 \mathrm{~cm})$ and leaf width $(9.96 \mathrm{~cm})$ were observed in $\mathrm{T}_{8}$ (75 \% RDF + Vermicompost+ PSB+ Azotobacter + sprayable macro and micro elements) and $\mathrm{T}_{7}(75 \% \mathrm{RDF}+$ Vermicompost + PSB + Azospirillum + sprayable macro and micro elements). It indicates that balanced fertilisation with organic and inorganic source of nutrient and foliar spray of nutrients encourage vegetative growth like leaf length, leaf width, and length of petiole while minimum value of these character was found in $\mathrm{T}_{2}$ (RDF in every month). 
This results was in alliance with the findings of Patil and Chaitra (2006) who stated that application of Azospirillum, Vermicompost, PSB and $50 \%$ RDF in China aster increased leaf length. Mathew and Shingh (2003) also reported increased leaf length in marigold due to application of Azotobacter, Azosprillum and PSB. Similar trends in leaf length and leaf width was also observed in summer and rainy season.

\section{Length of petiole}

It is evident from the Table-2 that in winter season maximum length of petiole was observed in $\mathrm{T}_{8}(12.36 \mathrm{~cm})$ and $\mathrm{T}_{7}$ receiving 75 $\%$ of RDF+ PSB+ Vermicompost+ Azospirillum/Azotobacter + sprayable macro and micro elements which was at par with $\mathrm{T}_{4}$ and $\mathrm{T}_{5}$ receiving $75 \%$ RDF+ PSB+ Vermicompost+ Azotobacter/Azospirillum. The minimum petiole length was found in $\mathrm{T}_{2}$ receiving $100 \%$ RDF in every month.

In summer season maximum length of petiole was found in $\mathrm{T}_{8}$ and $\mathrm{T}_{7}$ receiving $75 \% \mathrm{RDF}+$ PSB + Vermicompost+ Azotobacterl Azospirillum + sprayable macro and micro elements which was similar to $\mathrm{T}_{4}$ and $\mathrm{T}_{5}$ receiving $75 \%$ RDF+ $\mathrm{PSB}+\mathrm{VC}+$ Azospirillum/Azotobacter. The minimum leaf width was recorded in $\mathrm{T}_{2}$ receiving $100 \%$ RDF in every month. Similarly in rainy season longest petiole length was observed in $\mathrm{T}_{8}$ and $\mathrm{T}_{7}$ receiving $75 \% \mathrm{RDF}+\mathrm{VC}+\mathrm{PSB}+$ Azotobacter / Azospirillum + sprayable macro and micro element $(75 \% \mathrm{RDF}+\mathrm{VC}+\mathrm{PSB}+$ Azotobacterl Azospirillum). The minimum leaf width was found in $\mathrm{T}_{2}$ receiving $100 \%$ RDF in every month.

Increase in length of petiole in $\mathrm{T}_{7}$ and $\mathrm{T}_{8}$ in all the season might be due to beneficial effect of vermicompost incubated with bio-fertilizer and spray of macro and micro element. Foliar application macro and micro elements helps in quick absorption of nutrients through leaf encourage growth resulting longer leaf and petiole. Decrease in length of petiole might be due to toxicity effect of chemical fertilizer when applied @ 100 \% RDF in every month.

\section{Number of suckers/plant}

Pooled data form Tabel-2 reveals that in winter season maximum number of suckers (3.61 no.) was obtained in $\mathrm{T}_{8}(75 \% \mathrm{RDF}+$ Vermicopost $+\mathrm{PSB}+$ Azotobacter + sprayable macro and micro elements) and $\mathrm{T}_{7}(75 \%$ $\mathrm{RDF}+$ Vermicompost+ PSB+ Azospirillum + sprayable macro and micro elements). Increased number of suckers might be due to application of balanced fertiliser, bio-fertiliser with foliar application of macro and micro nutrients which encourage vegetative growth allowing more number of suckers per plant. Similar finding have been reported by Seetha and Gowda (2002) in gerbera. The minimum number of suckers (1.59 no.) in $\mathrm{T}_{2}$ (RDF in every month) might be due to supply of excess nutrients than the requirement resulting poor and sick growth of plants. Similar trends in number of suckers/plant were also observed in summer and rainy season.

\section{Leaf area}

Pooled data from Table-2 revealed that in winter season maximum leaf area (160.93 $\mathrm{cm}^{2}$ ) was recorded in $\mathrm{T}_{8}$ receiving $(75 \% \mathrm{RDF}$ + Vermicompost + PSB+ Azotobacter + sprayable macro and micro elements) which was at par with $\mathrm{T}_{7} \quad(75 \%$ RDF + Vermicompost + PSB + Azospirillum + sprayable macro and micro elements). It indicates that combined application of organic and inorganic source of nutrients enhance microbial activity in soil and supply nutrients to plant by solubilising/mobilizing nutrients in soil. The minimum leaf area $\left(91.78 \mathrm{~cm}^{2}\right)$ was observed in winter in $\mathrm{T}_{2}$ ( $\mathrm{RDF}$ in every month) might be due to poor and sick growth of plants due to application of fertilizer more than the requirement by application of RDF in 
every month. Similar trends in leaf area were also observed in summer and rainy season.

\section{Chlorophyll content}

From Table-2 it is evident that in winter season maximum chlorophyll content was observed in $\mathrm{T}_{8}(3.14 \mathrm{mg} / \mathrm{g}$ leaf $)$ and $\mathrm{T}_{7}(75 \%$ $\mathrm{RDF}+$ Vermicompost+ PSB + Azotobacterl Azospirillum+ sprayable macro and micro elements). The increase in chlorophyll content might be due to combined application of vermicompost, biofertiliser along with $75 \%$ of RDF. Application of bio-fertiliser incubated in vermicompost improve soil physical, chemical and biological properties which result in more availability of nutrient to plants and more assimilation of photosynthates. Similar finding have been obtained by Jagadish and Jayamma (2008) with respected to application of biofertiliser with $50 \%$ RDF in jasmine, Rodriguez (2000) with respect to application of vermicompost in gerbera and Singh et al., (2012) with respect to application of $\mathrm{ZnSO}_{4}, \mathrm{FeSO}_{4}$ as foliar spray in Lilium. Minimum chlorophyll content $(2.18 \mathrm{mg} / \mathrm{g}$ leaf $)$ in $\mathrm{T}_{2}$ in winter might be due to sick and poor growth of plant due to excess of inorganic fertiliser applied than the requirement of plant. Similar trends in chlorophyll content were also observed in summer and rainy season.

\section{Number of flowers $/ \mathrm{m}^{2} / \mathrm{month}$}

The pooled data from both the year (Table-3) revealed that there were maximum number of flowers (29.48) per $\mathrm{m}^{2} /$ month in winter in $\mathrm{T}_{8}$ (75 \% RDF+ vermicompost+ PSB+ Azotobacter+ sprayable macro and micro elements) which was at par with $\mathrm{T}_{7}(75 \%$ RDF+ vermicompost+ PSB+ Azospirillum + sprayable macro and micro elements) which were closely followed by $\mathrm{T}_{4}$ and $\mathrm{T}_{5}(75 \%$ $\mathrm{RDF}+$ Vermicompost + PSB + Azopirillum/ Azotobacter). This indicates that treatment with vermicompost and biofertiliser have higher capability of Carbon assimilation than other treatments. PSB solubilises insoluble and fixed from of $\mathrm{P}_{2} \mathrm{O}_{5}$ in soil making it's availability to plant. Similarly Azospirillum/ Azotobacter fix atmospheric $\mathrm{N}$ and supply to the plants. Vermicompost is rich source of macro nutrients and micro nutrient like $\mathrm{Zn}, \mathrm{Fe}$ etc which accelerates enzymatic activity in the plant. Besides, vermicompost has growth promoting effect due to presence of hormones. All of these organic source of nutrient might have augmented maximum dry matter accumulation in plant which resulted higher number of flower yield/plant/month than others. Similar results have been obtained by Seetha and Gowda (2002), Subramaniam (2002). Application of macro and micro elements in form of foliar spray augmented flower production in $T_{7}$ and $T_{8}$ which is in conformity with the finding of Muthumanickamm et al., (1999) with respect to application of $2 \% \mathrm{MnSO}_{4}, \mathrm{ZnSO}_{4}$ and $\mathrm{FeSO}_{4}$ as foliar spray in gerbera. The lowest flower yield (11.84) per $\mathrm{m}^{2} /$ month in winter in $\mathrm{T}_{2}$ (RDF in every month) may be due to excessive nutrient application in soil which create toxicity effect of fertilizer with sick and poor growth of plant resulting low carbon assimilation and so lowest number of flower/plant. Similar result of increased in number of flowers per $\mathrm{m}^{2} /$ month in summer and rainy season was observed in $\mathrm{T}_{8}$ and $\mathrm{T}_{7}(75 \%$ RDF + vermicompost $+\mathrm{PSB}+$ Azotobacter/Azospirillum + sprayable macro and micro elements).

From the above finding it can be concluded that application of $75 \%$ RDF $(15: 10: 30 \mathrm{~g}$ NPK/10 plants $)+$ Vermicompost+ $(25 \mathrm{~g} / 10$ plants $)+$ PSB $\left(20 \mathrm{~g} / \mathrm{m}^{2} 10\right.$ plants $)+$ Azospirillum/ Azotobacter (20g/10 plants) + macro and micro element spray increased all of vegetative parameters of gerbera with maximum number of flowers $/ \mathrm{m}^{2} /$ month. The result will be torch bearer for the researcher as well as gerbera grower for enhancing quality flower production under open field condition. 
Table.1 Treatment means (Pooled over year 2015-16 and 2016-17) for plant spread, number of leaves, leaf length and leaf width of gerbera (Shimmer)

\begin{tabular}{|c|c|c|c|c|c|c|c|c|c|c|c|c|c|}
\hline \multirow{2}{*}{$\begin{array}{l}\text { Treatmen } \\
\text { ts } \\
\text { number }\end{array}$} & \multirow[t]{2}{*}{ Treatment } & \multicolumn{3}{|c|}{ Plant spread(cm) } & \multicolumn{3}{|c|}{$\begin{array}{c}\text { Number of } \\
\text { leaves/plant }\end{array}$} & \multicolumn{3}{|c|}{ Leaf Length(cm) } & \multicolumn{3}{|c|}{ Leaf width(cm) } \\
\hline & & Winter & Summer & Rainy & Winter & Winter & Winter & Winter & Summer & Rainy & Winter & Summer & Rainy \\
\hline $\mathbf{T}_{1}$ & $\begin{array}{l}\text { RDF in alternate } \\
\text { month }\end{array}$ & 62.12 & 47.94 & 52.36 & 19.46 & 14.79 & 17.63 & 33.77 & 24.74 & 26.50 & 8.86 & 6.68 & 7.29 \\
\hline $\mathbf{T}_{2}$ & RDF in every month & 55.84 & 41.62 & 43.76 & 13.81 & 10.52 & 11.19 & 29.65 & 19.59 & 21.75 & 7.79 & 4.66 & 6.12 \\
\hline $\mathbf{T}_{\mathbf{3}}$ & $\begin{array}{l}75 \% \text { RDF + } \\
\text { Vermicompost }\end{array}$ & 57.98 & 46.71 & 50.83 & 17.07 & 13.77 & 15.69 & 31.43 & 23.18 & 24.42 & 8.38 & 6.00 & 6.79 \\
\hline $\mathbf{T}_{4}$ & $\begin{array}{l}75 \% \mathrm{RDF}+\mathrm{VC}+ \\
\text { Azospirillum + PSB }\end{array}$ & 71.29 & 53.67 & 56.72 & 22.17 & 19.67 & 21.61 & 37.05 & 27.91 & 31.46 & 9.62 & 7.37 & 8.42 \\
\hline $\mathbf{T}_{5}$ & $\begin{array}{l}75 \% \mathrm{RDF}+\mathrm{VC} \\
+ \text { Azotobacter }+\mathrm{PSB}\end{array}$ & 71.46 & 53.70 & 56.90 & 22.23 & 19.46 & 21.54 & 37.18 & 28.15 & 31.56 & 9.63 & 7.47 & 8.41 \\
\hline $\mathbf{T}_{6}$ & $\begin{array}{l}75 \% \mathrm{RDF}+\mathrm{VC}+ \\
\text { macro and micro } \\
\text { elements }\end{array}$ & 62.38 & 48.91 & 52.59 & 19.63 & 14.73 & 17.92 & 33.83 & 25.13 & 26.88 & 8.84 & 6.54 & 7.34 \\
\hline $\mathbf{T}_{7}$ & $\begin{array}{l}75 \% \mathrm{RDF}+\mathrm{VC}+ \\
\text { Azospirillum }+\mathrm{PSB}+ \\
\text { macro and } \\
\text { microelements }\end{array}$ & 77.19 & 58.61 & 59.67 & 25.23 & 22.21 & 24.29 & 39.93 & 31.04 & 34.27 & 9.92 & 8.19 & 8.93 \\
\hline $\mathbf{T}_{8}$ & $\begin{array}{l}75 \% \mathrm{RDF}+\mathrm{VC}+ \\
\text { Azotobacter }+\mathrm{PSB}+ \\
\text { macro and micro } \\
\text { elements }\end{array}$ & 77.15 & 58.65 & 59.97 & 25.21 & 22.36 & 24.42 & 39.98 & 31.04 & 34.44 & 9.96 & 8.17 & 8.91 \\
\hline & $\mathrm{SE}(\mathrm{m}) \pm$ & 2.488 & 1.716 & 1.235 & 1.876 & 0.648 & 0.675 & 0.336 & 1.396 & 0.737 & 0.276 & 0.160 & 0.223 \\
\hline & $\mathrm{CD}(0.05)$ & 8.32 & 5.74 & 4.13 & 6.27 & 2.17 & 2.26 & 0.96 & 4.67 & 2.46 & 0.92 & 0.54 & 0.75 \\
\hline
\end{tabular}


Table.2 Treatment means (Pooled over year 2015-16 and 2016-17) for length of petiole, number of suckers, leaf area and chlorophyll content of gerbera (Shimmer)

\begin{tabular}{|c|c|c|c|c|c|c|c|c|c|c|c|c|c|}
\hline \multirow[t]{2}{*}{$\begin{array}{l}\text { Treatments } \\
\text { number }\end{array}$} & \multirow[t]{2}{*}{ Treatment } & \multicolumn{3}{|c|}{ Length of petiole $(\mathrm{cm})$} & \multicolumn{3}{|c|}{$\begin{array}{c}\text { Number of } \\
\text { suckers/plant }\end{array}$} & \multicolumn{3}{|c|}{ Leaf $\operatorname{area}\left(\mathrm{cm}^{2}\right)$} & \multicolumn{3}{|c|}{$\begin{array}{c}\text { Chlorophyll } \\
\text { content(mg/g leaf) }\end{array}$} \\
\hline & & Winter & Summer & Rainy & Winter & Summer & Rainy & Winter & Summer & Rainy & Winter & Summer & Rainy \\
\hline $\mathbf{T}_{1}$ & $\begin{array}{l}\text { RDF in alternate } \\
\text { month }\end{array}$ & 9.88 & 6.24 & 8.38 & 2.63 & 1.65 & 2.23 & 125.99 & 101.02 & 116.21 & 2.52 & 1.62 & 2.09 \\
\hline $\mathbf{T}_{2}$ & RDF in every month & 8.74 & 4.66 & 7.03 & 1.59 & 1.02 & 1.41 & 91.78 & 55.43 & 70.92 & 2.18 & 1.07 & 1.68 \\
\hline $\mathbf{T}_{\mathbf{3}}$ & $\begin{array}{l}75 \% \mathrm{RDF}+ \\
\text { Vermicompost }\end{array}$ & 9.43 & 5.83 & 7.93 & 2.30 & 1.38 & 2.06 & 114.34 & 89.09 & 101.20 & 2.44 & 1.42 & 1.95 \\
\hline $\mathbf{T}_{4}$ & $\begin{array}{l}75 \% \mathrm{RDF}+\mathrm{VC}+ \\
\text { Azospirillum }+\mathrm{PSB}\end{array}$ & 10.60 & 7.60 & 9.28 & 3.13 & 2.21 & 2.77 & 139.85 & 114.25 & 135.38 & 2.82 & 1.72 & 2.29 \\
\hline $\mathbf{T}_{5}$ & $\begin{array}{l}75 \% \mathrm{RDF}+\mathrm{VC} \\
+ \text { Azotobacter }+\mathrm{PSB}\end{array}$ & 10.61 & 7.64 & 9.29 & 3.11 & 2.15 & 2.83 & 141.79 & 113.78 & 135.15 & 2.84 & 1.75 & 2.32 \\
\hline $\mathbf{T}_{6}$ & $\begin{array}{l}75 \% \mathrm{RDF}+\mathrm{VC}+ \\
\text { macro and micro } \\
\text { elements }\end{array}$ & 9.85 & 6.31 & 8.40 & 2.65 & 1.84 & 2.42 & 126.72 & 99.96 & 116.85 & 2.67 & 1.59 & 2.05 \\
\hline $\mathbf{T}_{7}$ & $\begin{array}{l}75 \% \mathrm{RDF}+\mathrm{VC}+ \\
\text { Azospirillum }+\mathrm{PSB}+ \\
\text { macro and } \\
\text { microelements }\end{array}$ & 12.33 & 8.70 & 9.93 & 3.57 & 2.71 & 3.19 & 160.33 & 131.33 & 150.74 & 3.08 & 2.07 & 2.55 \\
\hline \multirow[t]{3}{*}{$\mathbf{T}_{8}$} & $\begin{array}{l}75 \% \mathrm{RDF}+\mathrm{VC}+ \\
\text { Azotobacter }+\mathrm{PSB}+ \\
\text { macro and micro } \\
\text { elements }\end{array}$ & 12.36 & 8.67 & 9.96 & 3.61 & 2.65 & 3.21 & 160.93 & 131.30 & 150.62 & 3.14 & 2.08 & 2.58 \\
\hline & $\mathrm{SE}(\mathrm{m}) \pm$ & 0.604 & 0.302 & 0.370 & 0.155 & 0.056 & 0.061 & 2.430 & 2.351 & 5.701 & 0.093 & 0.102 & 0.041 \\
\hline & $\mathrm{CD}(0.05)$ & 2.02 & 1.01 & 1.24 & 0.52 & 0.16 & 0.17 & 6.95 & 6.72 & 19.06 & 0.31 & 0.34 & 0.12 \\
\hline
\end{tabular}


Table.3 Effect of INM on number of flowers $/$ plant $/ \mathrm{m}^{2} /$ month

\begin{tabular}{|c|c|c|c|c|}
\hline \multirow[t]{2}{*}{ Treatments number } & \multirow[t]{2}{*}{ Treatments } & \multicolumn{3}{|c|}{ Number of flowers $/ \mathrm{m}^{2} /$ month } \\
\hline & & Winter & Summer & Rainy \\
\hline $\mathbf{T}_{1}$ & RDF in alternate month & 21.03 & 17.84 & 19.86 \\
\hline $\mathbf{T}_{2}$ & RDF in every month & 11.84 & 10.95 & 11.61 \\
\hline $\mathbf{T}_{3}$ & $75 \%$ RDF + Vermicompost & 16.53 & 14.91 & 15.56 \\
\hline $\mathbf{T}_{4}$ & $75 \% \mathrm{RDF}+\mathrm{VC}+$ Azospirillum $+\mathrm{PSB}$ & 24.05 & 21.20 & 23.06 \\
\hline $\mathbf{T}_{5}$ & $75 \% \mathrm{RDF}+\mathrm{VC}+$ Azotobacter $+\mathrm{PSB}$ & 24.03 & 21.96 & 23.04 \\
\hline $\mathbf{T}_{6}$ & $75 \% \mathrm{RDF}+\mathrm{VC}+$ macro and micro elements & 22.53 & 18.57 & 20.43 \\
\hline $\mathbf{T}_{7}$ & $75 \% \mathrm{RDF}+\mathrm{VC}+$ Azospirillum $+\mathrm{PSB}+$ macro and microelements & 29.28 & 25.14 & 26.43 \\
\hline $\mathbf{T}_{8}$ & $75 \% \mathrm{RDF}+\mathrm{VC}+$ Azotobacter $+\mathrm{PSB}+$ macro and micro elements & 29.48 & 25.53 & 26.42 \\
\hline & $\mathrm{SE}(\mathrm{m}) \pm$ & 0.729 & 0.43 & 0.943 \\
\hline & $\mathrm{CD}(0.05)$ & 2.44 & 1.22 & 3.15 \\
\hline
\end{tabular}




\section{References}

Bose, T.K., Yadav, L. P., Pal, P., Parthasarathy, V.P. and Das, P. (2003). Commercial flowers $\left(2^{\text {nd }} \mathrm{Ed}\right.$.) Naya Udyog, Calcutta, India

Chauhan, N. (2005). Performance of gerbera genotype under protected cultivation. Dept. Hort., College of Agril. Dharwad Univs. Agril. Sci., Dharwad.

Gomez, K.A. and Gomez, A.A. (1984). Statistical procedure for agricultural research. John Willeyl Sons Inc., New York, Pp. 1-680.

Jagadeesh, K. S. and Jayamma, N. (2008). Response of jasmine to biofertilizer application M.Sc (Ag) Thesis submitted at UAS, Dharward.

Kathiresan, C. and Venkatesha, J. (2002). Studies on biofertilisers with $\mathrm{N}$ and $\mathrm{P}$ on gladiolus. Proceeding of the abstract, National Symposium on Indian floriculture in new millennium, (Feb: 25-27, 2002), PP:62.

Majumdar, J., Perinban, S., Tiwari, A.K., Saha, T. N. and Kumar, R. (2014). Integrated nutrient management in commercial flower crops. Progressive Research, 9(1): 28-32.

Mathew, B. and Singh, B. P. (2003). Effect of different Combination of biofertiliser on growth and yield of African marigold. Proceeding of the abstract, National
Symposium on recent Advances in Indian floriculture (Nov: 12-14, 2002), PP: 5.

Patra SK, Beura S and Sashani T. 2015. Efficacy of $\mathrm{GA}_{3}$ on growth and flowering regulation of in vitro raised hybrid gerbera under shade net. Agri. Sci. Digest, 35(3): 173-177.

Rodriquez, N.J.A., Zavaleta, M.E; Sanchez, G.P. and Gonzalez, R.H. (2000). Effect of vermicompost on Plant nutrition yield and incidence of root rotof Gerbera. Phytopathologia, 35 (1): 6679.

Seetha and Gowda, J.V. (2002). Effect of vermicompost and biofertilizer on gerbera. Proceeding of the abstract, National symposium on Indian floriculture in new millennium (Feb: 25-27, 2002), PP:24.

Subramanian, S., Jawaharal, M., Arumuam, T. Vijayakumar, M. (2002). Integrated nutrient management in crossandra. Proceeding of the abstract, National Symposium on Indian floriculture in new millennium (Feb:25-27, 2002) PP: 39.

Sujatha, K., Gowda, J.V.N. and Khan, M.M. (2002). Effect of different fertigation level on gerbera under low cost greenhouse. Journal of Orrnamental Horticulture, 5(1): 54-59.

\section{How to cite this article:}

Bishnupada Giri and Sashikala Beura. 2020. Impact of INM Practices on Vegetative Growth and Flowering of Hybrid Gerbera (Gerbera jamesonii B.) cv. Shimmer in Open Condition. Int.J.Curr.Microbiol.App.Sci. 9(06): 1680-1688. doi: https://doi.org/10.20546/ijcmas.2020.906.208 